\title{
Power Influence and Conflict Management of Ready-to-Wear (RTW) Store Supervisors
}

\author{
Kim Edward S. Santos ${ }^{1}$, Mary Chris Austria-Cruz ${ }^{2}$ \\ ${ }^{1}$ College of Management and Business Technology, Atate Campus, Nueva Ecija University of Science and Technology, Nueva \\ Ecija, Philippines \\ ${ }^{2}$ College of Management and Business Technology, Sumacab Campus, Nueva Ecija University of Science and Technology, \\ Nueva Ecija, Philippines \\ Email:kimnyte@gmail.com, kesantos@neust.edu.ph,maria_cristi@yahoo.com,marychrisaustria@neust.edu.ph
}

How to cite this paper: Santos, K.E.S. and Austria-Cruz, M.C. (2020) Power Influence and Conflict Management of Ready-to-Wear (RTW) Store Supervisors. Open Access Library Journal, 7: e6206.

https://doi.org/10.4236/oalib.1106206

Received: March 3, 2020

Accepted: March 21, 2020

Published: March 24, 2020

Copyright (C) 2020 by author(s) and Open Access Library Inc.

This work is licensed under the Creative Commons Attribution International License (CC BY 4.0).

http://creativecommons.org/licenses/by/4.0/

\section{(c) (i) Open Access}

\begin{abstract}
Conflict awareness would enable managers to tackle the problems of operational performance, sustainability, and governance, more efficiently and effectively. This paper described the Ready-to-Wear (RTW) Store Supervisors' personal power profile in terms of reward, coercive, legitimate, referent, and expert; and described the conflict management styles, such as competing, collaborating, compromising, avoiding and accommodating. Further, this paper determined Sex Difference on the Personal Power Profile and Conflict Management Styles of RTW Store Supervisors. This paper used descriptive method of research. The researchers distributed survey questionnaires to a total of 79 (33 males and 46 females) RTW store supervisors in Nueva Ecija with likert-scale responses and analyzed it through statistical data treatment such as mean, standard deviation and t-test. Based on the result of the study, the researchers concluded that, first, RTW store supervisors mostly prefer referent power in influencing their staff they will feel valued and personally accepted. Second, store supervisor least prefers coercive power to influence others. Third, in terms of conflict management styles, collaborating is always used, and accommodating and compromising are sometimes used as strategies in conflict situations. Last, there is sex difference in terms personal power profile and conflict management styles where female RTW store supervisors report higher on some domains as compared to male RTW store supervisors. In lieu of the forgoing conclusions, the researchers recommend that RTW store supervisors should strengthen the personal power profiles that recognize the value, accept strong relationship, give benefits needed, and show example of commitment. These powers are referent, expert and reward. Conflict situations are normal in any business; thus RTW store supervisors should develop skills in managing conflicts. Collaborating, accommodating and compromising are conflict management styles that often give positive results.
\end{abstract}


It is further recommended that regardless of sex difference, all store supervisors must have training to fully develop skills in managing conflicts.

\section{Subject Areas}

General Management, Human Resource Management, Management

Organization, Personnel and Industrial Relations

\section{Keywords}

Ready-to-Wear, Conflict Management, Power Profile, Management Style, Conflict Management Style

\section{Introduction}

Conflict awareness would enable managers to tackle the problems of operational performance, sustainability, and governance, more efficiently and effectively. Conflict is a phenomenon that affects the borders of organization, influencing people, communities and disciplines [1]. In the academe, principals feel it was more successful to resolve conflicts by discussing the issues individually with their staff [2].

Thus, managers need to effectively integrate all the tactics and methods to find a better approach to the conflicts between their workers and organizations [3]. Conflicts should be settled by first-line managers, or on the middle management tier, if the conflict is important [4]. Unresolved conflict poses the largest reducible expense for many companies, yet the revenue, human and reputation costs of organizational conflicts are not analyzed or proactively handled in most organizations [5].

A manager or supervisor with a high need for power will be more likely to choose Impersonal Coercive Power and Legitimate Position Power, so those with clear association needs are more likely to prefer Referent Power and Reward Power, especially Personal Reward Power, because their subordinate will like them [6].

\section{Conceptual Framework}

Different styles in conflict management lead to different attitudes in the conflict resolution process which also lead to different outcomes [7]. Task-oriented managers and non-managers prefer to use the competing mode more often, whereas relationship-oriented managers use more of accommodating style [8]. Managers seem to favor constructive approaches to coping with conflict situations, because controlling is used more often than non-confrontation [9].

There were distinguished five types of power: referent power, expert power, reward power, coercive power, and legitimate power [10]. Despite the authority bestowed on managers, characteristic of a high-power-distance society, their legitimate power was not adequate to contend with escalated conflicts as they of- 
ten needed leverage to reward power in order to make negotiation, reorganization and educational strategies work [11].

\section{Objectives of the Study}

This paper described the Ready-to-Wear (RTW) Store Supervisors' personal power profile in terms of reward, coercive, legitimate, referent, and expert; and described the conflict management styles such as competing, collaborating, compromising, avoiding, and accommodating. Further, this paper determined Sex Difference on the Personal Power Profile and Conflict Management Styles of RTW Store Supervisors.

\section{Methodology}

The study used descriptive method as it describes the present condition. The main objective of the study is to explore the causes of particular phenomenon. It further concern with the condition or relationship that exists; practices that prevail; and beliefs and processes that are going on; effects that being felt or trends that are developing [12].

The researchers distributed survey questionnaires with liker-scale responses [13] to a total of 79 (33 males and 46 females) Ready-To-Wear (RTW) Store Supervisors in Nueva Ecija and analyzed it through statistical data treatment such as mean, standard deviation and t-test.

\section{Results and Discussions}

Table 1 presents the personal power profile of RTW (Ready-to-Wear) Store Supervisors on how their influence others especially their staff. Based on the results, the five different influence powers are referent $(M=4.08, S D=0.422, V I=$ "agree"), expert ( $M=3.77, S D=0.511, V I=$ "agree"), reward $(M=3.58, S D=$ $0.548, V I=$ "agree"), legitimate $(M=3.51, S D=0.451, V I=$ "agree"), and coercive $(M=2.04, S D=0.243, V I=$ "disagree").

In referent power, RTW store supervisors make their staff feel valued ( $M=$ $4.29)$, personally accepted $(M=4.22)$ and important $(M=4.25)$. Expert power shows that supervisors provide their staff with sound job-related advice $(M=$ 3.99) and give good technical suggestions $(M=3.85)$. Moreover, if the supervisors hold reward power, they increase the pay level of his/her staff $(M=3.93)$ and provide them with special benefits $(M=3.66)$. Legitimate power shows that supervisors make their staff feel that they have commitments to meet $(M=3.68)$ and make them feel like they should satisfy their job requirements $(M=4.29)$. And, coercive power influences the supervisors to make things unpleasant for their staff $(M=2.73)$ and give undesirable job assignments.

The results imply that RTW store supervisors are influenced by referent power where strong relationship is given with much attention between them and the staff. Additionally, store supervisors did not opt to be influenced by coercive power which means they do not give any unpleasant and undesirable actions to their staff. 
Table 1. Personal power profile of RTW store supervisors.

\begin{tabular}{|c|c|c|c|c|}
\hline \multicolumn{2}{|c|}{ To influence others, I would prefer to: } & $M$ & $S D$ & VI \\
\hline \multicolumn{5}{|l|}{ A. Reward } \\
\hline \multicolumn{2}{|c|}{ 1. Increase their pay level } & 3.93 & 0.714 & A \\
\hline \multicolumn{2}{|c|}{ 2. Influence their getting a pay increase } & 3.38 & 0.820 & NAD \\
\hline \multicolumn{2}{|c|}{ 3. Provide them with special benefits } & 3.66 & 0.876 & $\mathrm{~A}$ \\
\hline \multicolumn{2}{|c|}{ 4. Influence their getting a promotion } & 3.34 & 0.731 & NAD \\
\hline \multicolumn{2}{|c|}{ Weighted Mean } & 3.58 & 0.548 & A \\
\hline \multicolumn{5}{|c|}{ B. Coercive } \\
\hline \multicolumn{2}{|c|}{ 1. Give undesirable job assignments } & 1.33 & 0.473 & SD \\
\hline \multicolumn{2}{|c|}{ 2. Make the work difficult for them } & 2.20 & 0.461 & $\mathrm{D}$ \\
\hline \multicolumn{2}{|c|}{ 3. Make things unpleasant here } & 2.73 & 0.842 & NAD \\
\hline \multicolumn{2}{|c|}{ 4. Make being at work distasteful } & 1.93 & 0.254 & $\mathrm{D}$ \\
\hline \multicolumn{2}{|c|}{ Weighted Mean } & 2.04 & 0.243 & $\mathrm{D}$ \\
\hline \multicolumn{5}{|c|}{ C. Legitimate } \\
\hline \multicolumn{2}{|c|}{ 1. Make them feel that they have commitments to meet } & 3.68 & 0.598 & A \\
\hline \multicolumn{2}{|c|}{ 2. Make them feel like they should satisfy their job requirements } & 3.56 & 0.986 & A \\
\hline \multicolumn{2}{|c|}{ 3. Give them the feeling that they have responsibilities to fulfill } & 3.46 & 0.502 & A \\
\hline \multicolumn{2}{|c|}{ 4. Make them recognize that they have tasks to accomplish } & 3.32 & 0.956 & $\mathrm{NAD}$ \\
\hline \multicolumn{2}{|c|}{ Weighted Mean } & 3.51 & 0.451 & A \\
\hline \multicolumn{5}{|l|}{ D. Referent } \\
\hline \multicolumn{2}{|c|}{ 1. Make them feel valued } & 4.29 & 0.943 & SA \\
\hline \multicolumn{2}{|c|}{ 2. Make them feel like I approve of them } & 3.55 & 0.680 & A \\
\hline \multicolumn{2}{|c|}{ 3. Make them feel personally accepted } & 4.22 & 0.676 & SA \\
\hline \multicolumn{2}{|c|}{ 4. Make them feel important } & 4.25 & 0.765 & SA \\
\hline \multicolumn{2}{|c|}{ Weighted Mean } & 4.08 & 0.422 & A \\
\hline \multicolumn{5}{|l|}{ E. Expert } \\
\hline \multicolumn{2}{|c|}{ 1. Give them good technical suggestions } & 3.85 & 0.908 & A \\
\hline \multicolumn{2}{|c|}{ 2. Share my experience and/or training } & 3.56 & 0.897 & A \\
\hline 3. Provide $\mathrm{t}$ & em with sound job-related advice & 3.99 & 0.593 & $\mathrm{~A}$ \\
\hline 4. Provide $\mathrm{t}$ & em with needed technical knowledge & 3.71 & 0.740 & $\mathrm{~A}$ \\
\hline Weighted & Iean & 3.77 & 0.511 & A \\
\hline Legend & Verbal Interpretation (VI) & & & \\
\hline $4.20-5.00$ & Strongly Agree (SA) & & & \\
\hline $3.40-4.19$ & Agree (A) & & & \\
\hline $2.60-3.39$ & Neither Agree nor Disagree (NAD) & & & \\
\hline $1.80-2.59$ & Disagree (D) & & & \\
\hline $1.00-1.79$ & Strongly Disagree (SD) & & & \\
\hline
\end{tabular}


Table 2 presents the conflict management styles of RTW store supervisors they use in conflict situations. Based on the results, the five conflict management styles are competing $(M=1.82, S D=0.336, V I=$ "sometimes"), collaborating ( $M=3.48, S D=0.121, V I=$ "always"), compromising $(M=3.13, S D=0.270, V I$ = "often"), avoiding ( $M=1.98, S D=0.392, V I=$ "sometimes"), and accommodating $(M=3.13, S D=0.252, V I=$ "often").

Table 2. Conflict management styles of RTW store supervisors.

\section{Competing}

1. I would argue my case and insist on the advantages of my point of view. $\quad \begin{array}{lll}1.97 & 0.769 & \text { S }\end{array}$

2. I find conflict exhilarating; I enjoy the battle of wits that unusually follows. $\begin{array}{llll}1.62 & 0.200 & R\end{array}$

3. I can figure out what needs to be done and I am usually right $\quad \begin{array}{llll}0.038 & \mathrm{~S}\end{array}$

Weighted Mean

$1.82 \quad 0.336 \quad S$

Collaborating

1. I discuss issues with others to try to find solutions that meet everyone's needs.

2. When there is a disagreement, I gather as much information as I can and keep the lines of communication open.

3. I try to see conflict from both sides.

Weighted Mean

\section{Compromising}

1. I try to negotiate and use give and take approach to problem situations.

3. To break deadlocks, I would meet people halfway.

Weighted Mean

\section{Avoiding}

1. When I find myself in an argument, I usually say very little and try to leave as soon as possible.

2. Being in a disagreement with other people makes me feel uncomfortable and anxious.

3. I avoid hard feelings by keeping my disagreements with others to my self

Weighted Mean

Accommodating

1. I try to meet the expectations of others.

2. I try to meet the wishes of my friends and family.

3. I may not get what I want but it's a small price to pay for keeping the peace.

Legend Verbal Interpretation (VI)

$3.25-4.00 \quad$ Always (A)

2.50 - 3.24 Often $(\mathrm{O})$

1.75 - 2.49 Sometime (S)

1.00 - 1.74 Rarely (R) 
RTW store supervisors mostly preferred collaborating style of conflict management wherein they always try to see conflict from both sides $(M=3.86)$. And, when there is a disagreement, they always gather as much information as they can and keep the lines of communication open $(M=3.62)$. In terms of other conflict management styles, the RTW store also preferred compromising and accommodating. In compromising styles, store supervisors always try to negotiate and use give and take approach to problem situations $(M=3.39)$. Accommodating style shows that the store supervisors may not get what they want but it's always a small price for them to pay for keeping the peace $(M=3.53)$.

On the other hand, RTW store supervisors least preferred avoiding and competing as their conflict management styles though they also use it sometimes.

Table 3 presents the sex difference of RTW store supervisors in terms of personal power profile and conflict management styles.

In terms of personal power profile, the result showed that there were significant differences. Female store supervisors reported higher level in terms of reward $(X=3.94, S D=0.548, t=2.34, p<0.05)$. Likewise, females also got higher level on legitimate styles $(X=3.62, S D=0.451, t=2.42, p<0.01)$ and in referent styles $(X=4.21, S D=0.422, t=2.96, p<0.05)$. The results implied female store supervisors showed more personal power profile to influence their staff as compared to male store supervisors. However, no sex difference was found in terms of coercive and expert personal power profile.

Table 3. Sex difference on the personal power profile and conflict management styles of RTW store supervisors.

\begin{tabular}{llll}
\hline & $\begin{array}{l}\text { Males } \\
\mathbf{n}=33 \\
(\text { Mean })\end{array}$ & $\begin{array}{l}\text { Females } \\
\mathbf{n}=46 \\
(\text { Mean })\end{array}$ & t-value \\
\hline Personal Power Profile & & & \\
\hline Reward & 3.22 & 3.94 & $2.34^{*}$ \\
Coercive & 2.01 & 2.07 & 1.99 \\
Legitimate & 3.40 & 3.62 & $2.42^{*}$ \\
Referent & 3.95 & 4.21 & $2.96^{*}$ \\
Expert & 3.80 & 3.74 & 1.87 \\
\hline Conflict Management Styles & & & 1.93 \\
\hline Competing & 1.89 & 1.75 & 0.95 \\
Collaborating & 3.45 & 3.51 & $2.82^{*}$ \\
Compromising & 3.09 & 3.18 & 1.09 \\
Avoiding & 2.01 & 1.95 & $2.06^{*}$ \\
Accommodating & 2.88 & 3.38 & \\
\hline
\end{tabular}

${ }^{* * *} p<0.001{ }^{* *} p<0.01{ }^{*} p<0.05$. 
Moreover, on the conflict management styles, female RTW store supervisors reported higher on compromising style $(X=3.18, S D=0.270, t=2.82, p<0.05)$ and accommodating style $(X=3.38, S D=0.252, t=2.06, p<0.05)$ as compared to male store supervisors in handling conflict situations. This result implies that females are more concerned with both their goals and their relationships with others. They seek a conflict solution in which both sides gain something. Female store supervisors also prefer to avoid conflict because they believe addressing it will damage relationships.

\section{Conclusions}

Based on the result of the study, the researchers concluded that, first, RTW store supervisors mostly prefer referent power in influencing their staff they will feel valued and personally accepted. Second, store supervisor least prefers coercive power to influence others. Third, in terms of conflict management styles, collaborating is always used and accommodating and compromising are sometimes used as strategies in conflict situations. Last, there is sex difference in terms of personal power profile and conflict management styles where female RTW store supervisors reported higher on some domains as compared to male RTW store supervisors.

\section{Recommendations}

In lieu of the forgoing conclusions, the researchers recommend that RTW store supervisors should strengthen the personal power profiles that recognize the value, accept strong relationship, give benefits needed, and show example of commitment. These powers are referent, expert and reward. Conflict situations are normal in any business; thus RTW store supervisors should develop skills in managing conflicts. Collaborating, accommodating and compromising are conflict management styles that often give positive results. It is further recommended that regardless of sex difference, all store supervisors must have training to fully develop skills in managing conflicts.

\section{Conflicts of Interest}

The authors declare no conflicts of interest regarding the publication of this paper.

\section{References}

[1] Kazimoto, P. (2013) Analysis of Conflict Management and Leadership for Organizational Change. International Journal of Research in Social Sciences, 3, 16-25.

[2] Riasi, A. and Asadzadeh, N. (2015) The Relationship between Principals' Reward Power and Their Conflict Management Styles Based on Thomas-Kilmann Conflict Mode Instrument. Management Science Letters, 5, 611-618. https://doi.org/10.5267/j.msl.2015.4.004

[3] Prause, D. and Mujtaba, B.G. (2015) Conflict Management Practices for Diverse Workplaces. Journal of Business Studies Quarterly, 6, 13. 
[4] Spaho, K. (2013) Organizational Communication and Conflict Management. Management-Journal of Contemporary Management Issues, 18, 103-118.

[5] Buss, H. (2011) Controlling Conflict Costs: The Business Case of Conflict Management. Journal of the International Ombudsman Association, 4, 54-62.

[6] Raven, B.H. (2008) The Bases of Power and the Power/Interaction Model of Interpersonal Influence. Analyses of Social Issues and Public Policy, 8, 1-22. https://doi.org/10.1111/j.1530-2415.2008.00159.x

[7] Ma, Z. (2007) Chinese Conflict Management Styles and Negotiation Behaviours: An Empirical Test. International Journal of Cross Cultural Management, 7, 101-119. https://doi.org/10.1177/1470595807075177

[8] Altmäe, S., Türk, K. and Toomet, O.S. (2013) Thomas-Kilmann's Conflict Management Modes and Their Relationship to Fiedler's Leadership Styles (Basing on Estonian Organizations). Baltic Journal of Management, 8, 45-65. https://doi.org/10.1108/17465261311291650

[9] Reuver, R.D. (2006) The Influence of Organizational Power on Conflict Dynamics. Personnel Review, 35, 589-603. https://doi.org/10.1108/00483480610682307

[10] French, J.R. and Raven, B. (2004) The Bases of Social Power. In: Cartwright, D., Ed., Studies in Social Power, Institute for Social Research, Ann Arbor, MI, 150-167.

[11] Kozan, M.K., Ergin, C. and Varoglu, K. (2014) Bases of Power and Conflict Intervention Strategy: A Study on Turkish Managers. International Journal of Conflict Management, 25, 38-60. https://doi.org/10.1108/IJCMA-05-2012-0041

[12] Cohen, L., Manion, L. and Morrison, K. (2002) Research Methods in Education. Routledge, London.

[13] Bertram, D. (2007) Likert Scales. 